\title{
Sexual Diagnosis Through Morphometric Evaluation of the Proximal Femur
}

\author{
El Diagnóstico Sexual a través de la Evaluación Morfométrica del Fémur Proximal
}

\author{
Vitor Caiaffo'; ${ }^{1}$ Pedro Paulo Feitosa de Albuquerque ${ }^{2}$; \\ Priscilla Virgínio de Albuquerque ${ }^{3}$ \& Belisa Duarte Ribeiro de Oliveira ${ }^{4}$
}

CAiffFo, V.; AlbuQuerque, P. P. F.; AlbUQUerQUE, P. V. \& OliveirA, B. D. R. Sexual diagnosis through morphometric evaluation of the proximal femur. Int. J. Morphol., 37(2):391-396, 2019.

SUMMARY: The determination of variables such as age, height, ethnicity and sex are extremely important to the identification of biological findings, especially in accidents with fatal victims. The diagnosis of sex can be $100 \%$ certain for cases in which the skeleton is complete and in a good state of conservation, the individual is an adult and the morphometric variables of the population to which the individual belongs are known.: The aim of the present study was to perform a morphometric evaluation of the proximal femur and compare measurements between males and females. Sixty pairs of femurs were acquired from the Department of Animal Morphology and Physiology of the Universidade Federal Rural de Pernambuco. The bones were measured with the aid of the ImageJ software program and the following variables were compared between bones from male and female cadavers: DFH - diameter of femoral head on the craniocaudal and sagittal axes; DFN - diameter of femoral neck on the craniocaudal and sagittal axes; FNL femoral neck length; ILL - intertrochanteric line length. The morphometric variables had the following mean values in the male bones: DFH-craniocaudal axis $-45.10 \pm 0.35 \mathrm{~mm}$; DFH-sagittal axis $-48.27 \pm 0.35 \mathrm{~mm}$; DFN-craniocaudal axis $-33.21 \pm 0.40 \mathrm{~mm}$; DFN-sagittal axis $-29.96 \pm 0.05 \mathrm{~mm}$; FNL $-31.71 \pm 0.05 \mathrm{~mm}$; ILL $-66.47 \pm 0.59 \mathrm{~mm}$. The mean values for the female bones were as follows: DFH-craniocaudal axis $-40.68 \pm 0.20 \mathrm{~mm}$; DFH-sagittal axis $-42.61 \pm 0.20 \mathrm{~mm}$; DFN-craniocaudal axis $-29.11 \pm 0.03$ $\mathrm{mm}$; DFN-sagittal axis $-26.05 \pm 0.04 \mathrm{~mm}$; FNL $-31.10 \pm 0.04 \mathrm{~mm}$; ILL $-60.80 \pm 0.41 \mathrm{~mm}$. With the exception of the femur neck length, all variables measurements were significantly larger $(\mathrm{p}<0.0001)$ on the male bones. The present findings demonstrate that the femur bone, particularly the proximal portion, exhibits important sexual dimorphism and has high potential for forensic purposes.

KEY WORDS: Morphometry; Proximal Femur; Morphology; Anatomy.

\section{INTRODUCTION}

The determination of variables such as age, height, ethnicity and sex are extremely important to the identification of biological findings, especially in accidents with fatal victims. However, the state in which a human body is found often provides little information when one uses techniques such as DNA testing. Thus, forensic anthropology fulfills this role and responsibilityregarding the identification of missing persons for cases in which the mortal remains are found skeletonized due to the action of time and/or external agents (Cuenca, 1994).

The determination of age and height is performed by a study of long bones. The determination of ethnicity is performed based on more detailed process that are not always reliable, such as the observation of facial angles, skull shape, cephalic indices and indices of the radius and humerus bones (Cuenca; Vioarsdóttir et al., 2002). The determination of sex is based on the comparative study of the bones encountered with standard reference data on bone morphology (Cuenca). This sexual diagnosis is considered to be one of the first essential steps toward a positive identification (Kranioti et al., 2009). According to Cuenca, the determination of sex can be $100 \%$ certain for cases in which (1) the skeleton is complete and in a good state of conservation; (2) the individual is an adult; and (3) the morphometric variables of the population to which the individual belongs are known.

Studies have determined the morphometric patterns for some bones, such as the mandible, iliac bone, skull,

\footnotetext{
${ }^{1}$ Nucleus for Life Sciences, Agreste Academic Center, Federal University of Pernambuco, (UFPE), Caruaru, Brazil.

${ }^{2}$ Department of Veterinary Medicine, Federal Rural University of Pernambuco (UFRPE), Recife, PE, Brazil.

${ }^{3}$ Department of Animal Morphology and Physiology, Federal Rural University of Pernambuco (UFRPE), Recife, PE, Brazil.

${ }^{4}$ Department of Physiotherapy, Centro Universitário Tabosa de Almeida (ASCES-UNITA), Caruaru, PE, Brazil.
} 
pelvis and scapula, especially in European and American populations (Cunha 2001; Oliveira Costa et al., 2016). The bones of the skull and pelvis form a set of the most used and efficient characters in morphological evaluations (Cunha).

Since it is not always possible to recover the pelvis and skull in forensic contexts, other bones of the skeleton have been tested for purposes of sexual diagnosis (Bruzek $\&$ Murail, 2006), such as the tibia, femur, radius, ulna, mandible and scapula (Oliveira Costa et al.; Lucena dos Santos et al., 2018). The femur is the strongest and longest bone in the human skeleton and extends from the pelvis to the knee. At the proximal portion, the femur is formed by the head, the anatomical neck (uniting the head to the trochanters), greater and lesser trochanters (which serve as the site of insertion for the muscles) and the surgical neck (uniting the diaphysis to the proximal epiphysis) (Mourão \& Vasconcellos, 2001). The femur forms the skeleton of the thigh, carries the weight of the body, supports the movement of the legs, provides fixation for the muscle, and stores blood cells, calcium and phosphate (Chowdhury et al., 2013).

Knowledge of the morphometric characteristics of the proximal femur is important to reducing the risk of complications related to surgical procedures in the area due to vascular, metabolic or traumatic causes and to enable the alignment of prostheses to be implanted (Mahaisavariya et al., 2002). Morphometric studies on the proximal femur have been conducted in different populations and communities (Mahaisavariya et al.; ElKaissi et al., 2005; de Sousa et al., 2010) and the data from these studies demonstrate regional and social differences in the morphometrics of this bone.

An investigation of the morphometric characteristics of the proximal femur in dry bones and the standardization of data for a given population are of considerable importance to the determination of risk factors in pathological conditions, preoperative planning and the design of the components of prostheses (Noble et al., 1988; Rubin et al., 1992; Chin et al., 1997; Bergot et al., 2002; Khang et al., 2003; Irdesel \& Ari, 2006; Atilla et al., 2007).

Therefore, given the importance of the morphological and morphometric study of the femur as well as the establishment of femoral morphometric patterns and the identification of sexual dimorphism in the proximal femur, the aim of the present study was to evaluate morphometric differences in variables of the proximal femur between bones from male and female cadavers.

\section{MATERIAL AND METHOD}

One hundred twenty femurs (60 pairs) were examined: 58 (29 pairs) from male cadavers and 62 (31 pairs) from female cadavers. The bones were acquired from the Anatomy Sector of the Department of Animal Morphology and Physiology of the Federal Rural University of Pernambuco and were originally from the Santo Amaro Public Cemetery in the city of Recife, Brazil. This study received approval from the Research Ethics Committee of the Pernambuco University (process number: 1.307.166; certificate number: 49926115.9.0000.5207). The bones used in the study were obtained from individuals buried between December 2009 and March 2012 and exhumed between in April and May 2014.

The inclusion criteria were femurs from individuals older than 18 years of age at the time of death and intact femurs with no signs of trauma and no apparent anomalies. The exclusion criteria were femurs with any type of anomaly, those in an advanced state of deterioration at the measurement sites, those with apparent trauma and those from individuals who were less than 18 years of age at the time of death. According to Almeida \& Costa (1977), differences between sexes are only evident after puberty and are influenced by the environment, hormones and musculature.

After cleaning and identification, the bones were photographed using a professional digital camera (Canon ${ }^{\circledR}$ - model 40D) set on automatic capture using a $50 \mathrm{~mm}$ lens, which was positioned on a tripod at a distance of $61 \mathrm{~cm}$ from the base on which the bones were placed. The measurements were subsequently made on the digital images with the aid of the ImageJ ${ }^{\circledR}$ software, version 1.47.

The morphometric evaluation consisted of the following variables: DFH - diameter of femoral head on the cranio-caudal axis (distance along a straight line from the upper limb to the lower limb of the head of the femur) and sagittal axis (distance along a straight line from the anterior portion to the posterior portion of the head of the femur); DFN - diameter of femoral neck on the cranio-caudal axis (distance along a straight line from the anterior portion to the posterior portion of the anatomical neck of the femur) and sagittal axis (distance along a straight line from the upper limb to the lower limb of the anatomical neck of the femur); FNL - femoral neck length (distance along a straight line between the lower region of the head of the femur to the base of the greater trochanter); and ILL - intertrochanteric line length (distance along a straight line that unites the highest points of the greater and lesser trochanters anteriorly) (Mourao \& Vasconcelos, 2001; Murlimanju et al., 2012; Iyem et al., 2013; Menezes et al., 2015) (Fig. 1). 

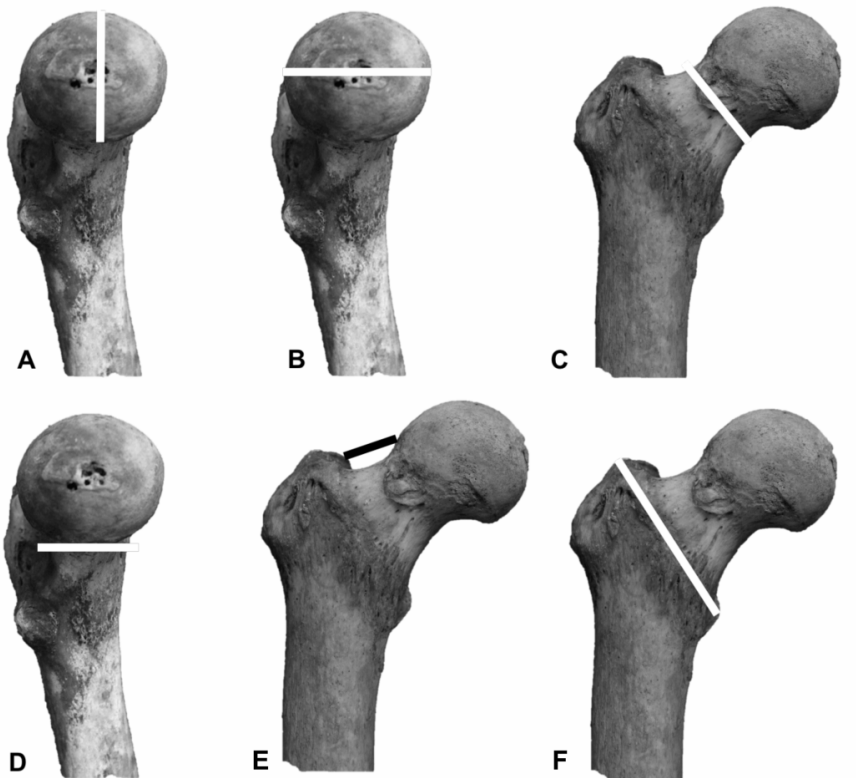

Fig. 1. Representation of morphometric measurements: A) diameter of femoral head on cranio-caudal axis; B) diameter of femoral head on sagittal axis; C) diameter of femoral neck on cranio-caudal axis; D) diameter of femoral neck on sagittal axis; E) femoral neck length; F) intertrochanteric line length. Images of measurements performed with ImageJ $₫$ software.

After the measurements, the respective mean and median (depending on the distribution [normal or non-normal] of the data) and standard deviation values were calculated for each measurement. The Kolmogorov-Smirnov normality test was used to determine the distribution of the data with the aid of GraphPad Prism 5.01. The Student's t-test was used for the comparison of the means of data with normal distribution. The Mann-Whitney test was used for the comparison of medians of data with non-normal distribution. The level of significance was set to $5 \%(\mathrm{p}<0.05)$ and all measurements were made with a margin of safety with $95 \%$ reliability.

\section{RESULTS}

Table I displays the values (in mm) of the morphometric variables of the proximal femur from males and females and differences between sexes. The measurements on the male bones were significantly larger than those on the female bones for all variables, except femoral neck length (Table I).

\section{DISCUSSION}

The present morphometric findings demonstrate sexual dimorphism in the proximal epiphysis of the femur. For nearly
Table I. Values (in $\mathrm{mm}$ ) of morphometric variables of proximal femur from males and females and differences between sexes.

\begin{tabular}{|c|c|c|c|}
\hline Parameters & Male & Female & $p$-value \\
\hline \multicolumn{4}{|c|}{ DFH - cranio-caudal axis } \\
\hline Mean & 45.09 & 40.65 & \multirow{5}{*}{$<0.0001 *$} \\
\hline Median & 45.90 & 40.26 & \\
\hline SD & 0.35 & 0.20 & \\
\hline Min & 34.87 & 36.15 & \\
\hline Max & 50.26 & 44.87 & \\
\hline \multicolumn{4}{|c|}{ DFH - sagittal axis } \\
\hline Mean & 48.26 & 42.54 & \multirow{5}{*}{$<0.0001 * *$} \\
\hline $\mathrm{SD}$ & 0.35 & 0.20 & \\
\hline Median & 48.97 & 41.79 & \\
\hline Min & 37.18 & 38.72 & \\
\hline $\operatorname{Max}$ & 55.90 & 47.69 & \\
\hline \multicolumn{4}{|c|}{ DFN - cranio-caudal axis } \\
\hline Mean & 33.21 & 29.11 & \multirow{5}{*}{$<0.0001 *$} \\
\hline SD & 0.30 & 0.23 & \\
\hline Median & 33.2 & 28.88 & \\
\hline Min & 26.83 & 25.39 & \\
\hline Max & 41.09 & 36.23 & \\
\hline \multicolumn{4}{|c|}{ DFN - sagittal axis } \\
\hline Mean & 29.96 & 26.05 & \multirow{5}{*}{$<0.0001 *$} \\
\hline $\mathrm{SD}$ & 0.42 & 0.29 & \\
\hline Median & 29.23 & 25.38 & \\
\hline Min & 22.57 & 21.79 & \\
\hline $\operatorname{Max}$ & 40.99 & 35.39 & \\
\hline \multicolumn{4}{|l|}{ FNL } \\
\hline Mean & 31.70 & 31.09 & \multirow{5}{*}{0.7963} \\
\hline SD & 0.37 & 0.32 & \\
\hline Median & 31.66 & 30.83 & \\
\hline Min & 22.86 & 20.79 & \\
\hline Max & 42.02 & 40.05 & \\
\hline \multicolumn{4}{|l|}{ ILL } \\
\hline Mean & 66.46 & 60.80 & \multirow{5}{*}{$<0.0001 * *$} \\
\hline SD & 0.59 & 0.42 & \\
\hline Median & 67.71 & 60.57 & \\
\hline Min & 49.34 & 52.77 & \\
\hline Max & 75.41 & 71.35 & \\
\hline
\end{tabular}

DFH - cranio-caudal axis (diameter of femoral head on cranio-caudal axis), DFH - sagittal axis (diameter of femoral head on sagittal axis), DFN - cranio-caudal axis (diameter of femoral neck on craniocaudal axis), DFN - sagittal axis (diameter of femoral neck on sagittal axis), FNL (femoral neck length), ILL (intertrochanteric line length), $\mathrm{p}<0.0001$. Student's t-test. ** Mann-Whitney Test.

all variables analyzed, femurs from male cadavers had larger measurements than those from female cadavers. No comparison was performed of the right and left sides due to the absence of data on the dominant limb, which is a factor that can exert an influence on bone morphology.

The length of the neck of the femur was the only variable for which no significant difference between sexes was found. Analyzing radiographs of the proximal femur, 
de Farias et al. (2015) demonstrated differences between males and females regarding the width and length of the neck, length of the femoral axis and neck-diaphyseal angle. The authors found larger values for males $(38.54 \mathrm{~mm} \pm 4.72$ $\mathrm{mm}, \mathrm{p}<0.0001)$. In the present study, the mean was $31.71 \pm$ $0.05 \mathrm{~mm}$ for males and $31.10 \pm 0.048$ for females. Performing morphometrics with the aid of digital calipers, Mourão \& Vasconcellos found a mean of femoral neck length of 24.6 $\pm 4.35 \mathrm{~mm}$. Using digital morphometry with the aid of the AutoCad software, de Sousa et al. found a mean of 30.30 $\pm 4.2 \mathrm{~mm}$. Pires et al. (2012) also used radiographs to measure the length of the femoral neck and found a mean of $35.70 \pm 6.4 \mathrm{~mm}$. Measuring the femoral neck on the Indian population with the aid of calipers, Verma et al. (2017) found a mean of $44.75 \pm 8.09 \mathrm{~mm}$. The last four studies did not perform a comparison between the sexes. The differences in values may be due to the different methods employed to perform the measurements and the different populations analyzed.

Regarding the diameter of the femoral head, Igbigbi \& Msamati (2000) examined radiographs and found higher values for both the vertical diameter $(48.30 \pm 3.51 \mathrm{~mm}, \mathrm{p}$ $=0.001)$ and transverse diameter $(50.55 \pm 3.32 \mathrm{~mm}$, $\mathrm{p}<0.001)$ of the head of the femur in males compared to females. Afroze \& Huda (2005) also used radiographs and found differences between sexes in the diameter of the femoral head in individuals from northeastern Bangladesh. In males, the authors found a mean of $51.55 \pm 1.30 \mathrm{~mm}(\mathrm{p}$ $<0.001$ ) for the vertical diameter and $42.20 \pm 1.33 \mathrm{~mm}$ (p $<0.001)$ for the transverse diameter. In the present study, sexual dimorphism was also found, with larger values for males regarding both the vertical diameter (DFH - craniocaudal axis: $45.10 \pm 0.35 \mathrm{~mm}, \mathrm{p}<0.0001)$ and transverse diameter (DFH - sagittal axis: $48.27 \pm 0.35 \mathrm{~mm}$, p < $0.0001)$. Using classic osteometry and radiography, Kanioti et al. (2009) found a mean of $46.99 \pm 2.47 \mathrm{~mm}$ for males and $42.44 \pm 2.26 \mathrm{~mm}$ for females, but did not find sexual dimorphism. Using different forms of mechanical (ring gauge and vernier calipers) and radiographic (radiographs and tomograms) measurements, Athapattu et al. (2014), found the following mean values: ring gauge $-47.8 \pm 5 \mathrm{~mm}$; vernier calipers $-47.69 \pm 4 \mathrm{~mm}$; $\mathrm{x}$-ray $-48.91 \pm 5.31 \mathrm{~mm}$; tomography $-48.02 \pm 5.5 \mathrm{~mm}$. Using digital calipers, Verma $e t \mathrm{al}$. found a mean of $42.32 \pm 4.11 \mathrm{~mm}$ for the diameter of the femoral head on the cranio-caudal axis in the Indian population. However, the latter two studies did not perform a comparison of the sexes.

Regarding the width of the femoral neck, Mourão \& Vasconcellos found a mean of $26.7 \pm 3.1 \mathrm{~mm}$ for the right side and $26.3 \pm 3.3 \mathrm{~mm}$ for the left side, demonstrating no significant differences between sides and the authors did not perform a comparison of the sexes. Using morphometry on radiographs, Kranioti et al. found a mean of $34.41 \pm 2.80 \mathrm{~mm}$ for men and $29.90 \pm 2.66 \mathrm{~mm}$ for women, but this difference did not achieve statistical significance. de Sousa et al. found a mean of $31.45 \pm 2.8$ $\mathrm{mm}$ for this variable, and Pires et al. found a mean of 36.60 $\pm 4.8 \mathrm{~mm}$. Analyzing an Indian population, Verma et al., found a mean of $24.01 \pm 3.05 \mathrm{~mm}$, but like Mourão \& Vasconcellos, de Sousa et al. and Pires et al. did not perform a comparison of the sexes. Using radiographs for the measurements, de Farias et al. found a significant difference between sexes, with a mean of $40.39 \pm 3.98$ $\mathrm{mm}$ for males and $34.68 \pm 3.19 \mathrm{~mm}$ for females $(\mathrm{p}<$ 0.001). In the present study, we employed digital morphometrics (ImageJ ${ }^{\circledR}$ version 1.47) and also found a difference between the sexes with regard to the width of the femoral neck.

Unlike the studies cited, the width of the femoral neck was analyzed on two axes in the present investigation: the longitudinal (cranio-caudal) and sagittal (Fig. 1), demonstrating differences in the two variables. The mean on the longitudinal axis was $33.21 \pm 0.040$ for males and $29.11 \pm 0.034$ for females $(\mathrm{p}<0.0001)$. On the sagittal axis, the mean width of the femoral neck was $29.96 \pm 0.058 \mathrm{~mm}$ for men and $26.05 \pm 0.044 \mathrm{~mm}$ for females ( $<0.0001$ ). The mean for the longitudinal (cranio-caudal) axis (33.21 \pm $0.040 \mathrm{~mm}$ ) is similar to the value found in the other studies, in which this variable was only evaluated on this axis. The slight differences in the width of the femoral neck among the studies cited and the present investigation may be due to regional, cultural and population differences among the different regions in Brazil.

Differences between sexes were also found regarding the length of the intertrochanteric line in the present study: $66.47 \pm 0.59 \mathrm{~mm}$ for males and $60.80 \pm 0.42 \mathrm{~mm}$ for females ( $\mathrm{p}<0.0001)$. Isaac et al. (1997) also measured the intertrochanteric line and found a mean of $57.9 \pm 6.7 \mathrm{~mm}$, but did not perform a comparison between the sexes. However, Isaac et al. states that this variable is positively correlated with total femur length. As women generally have a shorter height in comparison to men, this may also be an important variable for the definition of the sexual dimorphism of the femur.

\section{CONCLUSION}

The present findings demonstrate that the femur bone, particularly the proximal portion, exhibits important sexual 
dimorphism and has considerable potential for forensic purposes. The measurements performed (diameter of femoral head, diameter of femoral neck, femoral neck length and intertrochanteric line length) can serve as the basis for the identification of sex and may also serve as the basis for the formation of a reference standard for the Brazilian population.

These data underscore the need for further studies that use this bone as a tool for personal identification. Measures of the proximal portion of the femur can be useful for cases in which other methods are not applicable, increasing the gamut of options for forensic research teams.

\section{CAIAFFO, V.; ALBUQUERQUE, $\quad$ P. $\quad$ P. $\quad$ F.;} ALBUQUERQUE, P. V. \& OLIVEIRA, B. D. R. El diagnóstico sexual a través de la evaluación morfométrica del fémur proximal. Int. J. Morphol., 37(2):391-396, 2019.

RESUMEN: La determinación de variables como la edad, la altura, el origen étnico y el sexo son extremadamente importantes para la identificación de los hallazgos biológicos, especialmente en accidentes con víctimas fatales. El diagnóstico de sexo puede entregar una coincidencia del $100 \%$ para los casos en los que el esqueleto está completo y en un buen estado de conservación, el individuo es un adulto y se conocen las variables morfométricas de la población a la que pertenece el individuo. El objetivo del presente estudio consistió en realizar una evaluación morfométrica del fémur proximal y comparar las mediciones entre hombres y mujeres. Se adquirieron sesenta pares de fémures del Departamento de Morfología y Fisiología Animal de la Universidade Federal Rural de Pernambuco. Los huesos se midieron con la ayuda del programa de software ImageJ y se compararon las siguientes variables entre los huesos de cadáveres masculinos y femeninos: DCF: diámetro de la cabeza femoral en los ejes craneocaudal y sagital; DCF: diámetro del cuello femoral en los ejes craneocaudal y sagital; LCF - longitud del cuello femoral; LLI - longitud de línea intertrocantérea. Las variables morfométricas tenían los siguientes valores medios en los huesos masculinos: Eje craniocaudal DCF - 45,10 $\pm 0,35 \mathrm{~mm}$; DCF-eje sagital - 48,27 $\pm 0,35 \mathrm{~mm}$; DCF-eje craneocaudal - 33,21 $\pm 0,40 \mathrm{~mm}$; DFN-eje sagital - 29,96 $\pm 0,05$ $\mathrm{mm}$; LCF - 31,71 $\pm 0,05 \mathrm{~mm}$; LLI - 66,47 $\pm 0,59 \mathrm{~mm}$. Los valores medios para los huesos femeninos fueron los siguientes: DCFeje craneocaudal - 40,68 \pm 0,20 mm; DCF-eje sagital - 42,61 \pm 0,20 mm; DCF-eje craneocaudal - 29,11 \pm 0,03 mm; DCF-eje sagital - 26,05 $\pm 0,04 \mathrm{~mm}$; LCF - 31,10 \pm 0,04 mm; LLI - 60,80 $\pm 0,41 \mathrm{~mm}$. Con la excepción de la longitud del cuello del fémur, todas las medidas variables fueron significativamente más grandes ( $p<0,0001)$ en los huesos masculinos. Los presentes hallazgos demuestran que el hueso del fémur, particularmente la porción proximal, exhibe un importante dimorfismo sexual y tiene un alto potencial para fines forenses.

PALABRAS CLAVE: Morfometría; Fémur Proximal; Morfología; Anatomía.

\section{REFERENCES}

Afroze, A. \& Huda, M. D. Femoral head diameters and sex differentiation in the northern zone (Rajshahi) of Bangladesh. J. Teach. Assoc., 18(2):84-8, 2005.

Almeida, A. J. \& Costa, J. B. O. Lições de Medicina Legal. $14^{\text {th }}$ ed. São Paulo, Companhia Editora Nacional, 1977.

Athapattu, M.; Saveh, A. H.; Kazemi, S. M.; Wang, B. \& Chizari, M. Measurement of the femoral head diameter at hemiarthroplasty of the hip. Procedia Technol., 17:217-22, 2014.

Atilla, B.; Oznur, A.; Caglar, O.; Tokgözoglu, M. \& Alpaslan, M. Osteometry of the femora in Turkish individuals: a morphometric study in 114 cadaveric femora as an anatomic basis of femoral component design. Acta Orthop. Traumatol. Turc., 41:64-8, 2007.

Bergot, C.; Bousson, V.; Meunier, A.; Laval-Jeantet, M. \& Laredo, J. D. Hip fracture risk and proximal femur geometry from DXA scans. Osteoporos. Int., 13(7):542-50, 2002.

Bruzek, J. \& Murail, P. Methodology and Reliability of Sex Diagnosis from the Skeleton. In: Schmitt, A.; Cunha, E. \& Pinheiro, J. (Eds.). Forensic Anthropology and Medicine: Complementary Sciences from Recovery to Cause of Death. Totowa,Humana Press, 2006. pp. 22542.

Chin, K.; Evans, M. C.; Cornish, J.; Cundy, T. \& Reid, I. R. Differences in hip axis and femoral neck length in premenopausal women of Polynesian, Asian and European origin. Osteoporos. Int., 7(4):3447, 1997.

Chowdhury, S.; Naushaba, H.; Begum, J.; Ahmed, S.; Khan, L. F.; Parash, T. H. \& Qashem, R. Morphometrical and topographical anatomy of position of nutrient foramen on fully ossified left femur. Delta Med. Coll. J., 1(1):13-5, 2013.

Cuenca, J. V. R. Introducción a la Antropología Forense: Análisis e Identificación de Restos Óseos Humanos. Bogotá, Universidad Nacional de Colombia, 1994.

Cunha, E. A Paleopatologia como Fator de Individualização em Antropologia Forense. Lição de Síntese. Provas de Agregação. Coimbra, Universidade de Coimbra, 2001.

de Farias, T. H. S.; Borges, V. Q.; de Souza, E. S.; Miki, N. \& Abdala, F. Estudo radiográfico dos aspectos anatômicos do fêmur proximal dos adultos brasileiros. Rev. Bras. Ortop., 50(1):16-21, 2015.

de Sousa, E. B.; Fernandes, R. M. P.; Mathias, M. B.; Rodrigues, M. R.; Ambram, A. J. \& Babinski, M. A. Morphometric study of the proximal femur extremity in Brazilians. Int. J. Morphol., 28(3):83540, 2010.

El-Kaissi, S.; Pasco, J. A.; Henry, M. J.; Panahi, S.; Nicholson, J. G.; Nicholson, G. C. \& Kotowicz, M. A. Femoral neck geometry and hip fracture risk: the Geelong osteoporosis study. Osteoporos. Int., 16(10):1299-303, 2005.

Igbigbi, P. S. \& Msamati, B. C. Sex determination from femoral head diameters in black Malawians. East Afr. Med. J., 77(3):147-51, 2000.

Irdesel, J. \& Ari, I. The proximal femoral morphometry of Turkish women on radiographs. Eur. J. Anat., 10(1):21-6, 2006.

Isaac, B.; Vettivel, S.; Prasad, R.; Jeyaseelan, L. \& Chandi, G. Prediction of the femoral neck-shaft angle from the length of the femoral neck. Clin. Anat., 10(5):318-23, 1997.

Iyem, C.; Güvençer, M.; Karatosun, V. \& Unver, B. Morphometric evaluation of proximal femur in patients with unilateral total hip prosthesis. Clin. Anat., 27(3):478-88, 2013.

Khang, G.; Choi, K.; Kim, C. S.; Yang, J. S. \& Bae, T. S. A study of Korean femoral geometry. Clin. Orthop. Relat. Res., (406):116-22, 2003.

Kranioti, E. F.; Vorniotakis, N.; Galiatsou, C.; Is scan, M. Y. \& Michalodimitrakis, M. Sex identification and software development using digital femoral head radiographs. Forensic Sci. Int., 189(13):113.e1-7, 2009. 
Lucena dos Santos, E. R. S.; Albuquerque, P. P. F.; Albuquerque, P. V.; Oliveira, B. D. R. \& Caiaffo, V. Determination of sex based on the morphometric evaluation of the proximal tibia. Int. J. Morphol., 36(1):104-8, 2018.

Mahaisavariya, B.; Sitthiseripratip, K.; Tongdee, T.; Bohez, E. L.; Vander Sloten, J. \& Oris, P. Morphological study of the proximal femur: a new method of geometrical assessment using 3-dimensional reverse engineering. Med. Eng. Phys., 24(9):617-22, 2002.

Menezes, T. M; Rocha, T. D. S.; Oliveira, B. D. R.; Albuquerque, Y. M. L. \& Caiaffo, V. Proximal femoral epiphysis: manual morphometry versus digital morphometry. Int. J. Morphol., 33(3):1114-9, 2015.

Mourão, A. L. M. \& Vasconcellos, H. A. Geometria do fêmur proximal em ossos de brasileiros. Rev. Acta Fisiátr., 8(3):113-9, 2001.

Murlimanju, B. V.; Prabhu, L. V.; Pai, M. M.; Kumar, B. M.; Dhananjaya, K. V. N. \& Prashanth, K. U. Osteometric study of the upper end of femur and its clinical applications. Eur. J. Orthop. Surg. Traumatol., 22(3):227-30, 2012.

Noble, P. C.; Alexander, J. W.; Lindahl, L. J.; Yew, D. T.; Granberry, W. M. \& Tullos, H. S. The anatomic basis of femoral component design. Clin. Orthop. Relat. Res., (235):148-65, 1988.

Oliveira Costa, A. C.; Feitosa de Albuquerque, P. P. F.; de Albuquerque, P. V.; Ribeiro de Oliveira, B. D.; Lima de Albuquerque, Y. M. \& Caiaffo, V. Morphometric analysis of the scapula and their differences between females and males. Int. J. Morphol., 34(3):1164-8, 2016.

Pires, R. E. S.; Prata, E. F.; Gibram, A. V.; Santos, L. E. N.; Lourenço, P. R. B. T. \& Belloti, J. C. Radiographic anatomy of the proximal femur: correlation with the occurrence of fractures. Acta Ortop. Bras., 20(2):79-83, 2012.

Rubin, P. J.; Leyvraz, P. F.; Aubaniac, J. M.; Argenson, J. N.; Estève, P. $\&$ de Roguin, B. The morphology of the proximal femur. A threedimensional radiographic analysis. J. Bone Joint Surg. Br., 74(1):2832, 1992.

Verma, M.; Joshi, S.; Tuli, A.; Raheja, S.; Jain, P. \& Srivastava, P. Morphometry of proximal femur in Indian population. J. Clin. Diagn. Res., 11(2):AC01-AC04, 2017.

Vioarsdóttir, U. S.; O'Higgins, P. \& Stringer, C. A geometric morphometric study of regional differences in the ontogeny of the modern human facial skeleton. J. Anat., 201(3):211-29, 2002.
Corresponding author:

Vitor Caiaffo

Nucleus for Life Sciences

Agreste Academic Center

Federal University of Pernambuco, (UFPE)

Av. Oswaldo Cruz, n. 272 - Ap. 1301

Maurício de Nassau

Caruaru, PE

BRAZIL

E-mail: vitor.caaufpe@gmail.com

Received: 29-08-2018

Accepted: 17-12-2018 